\title{
Matters of age: An introduction to ageing, intergenerationality and gender in Africa
}

Vasu Reddy \& Nadia Sanger

"Old age is not pleasant; it buggers up your life" (Khushwant Singh, The freethinker's prayer book, 2012: vii)

"to jump from the ageing body to Death/has suddenly become a cop-out act" (Antjie Krog, Body Bereft, 2006: 20)

\begin{abstract}
This introductory essay to this special issue of Agenda draws together a wideranging, cross-disciplinary literature on ageing, intergenerationality and gender, and locates the significance of writing from Africa within this context. The first half of the essay provides a critical and comprehensive review of available literature in the field, highlighting the significance of research and writing on the ways in which gender mediates ageing and intergenerationality as both process and emotional space. The latter half of the essay engages the significance of the depth of contributions in this issue as critical in the conversation around ageing, gender, and intergenerationality in the context of Africa and the South, and the need for perspectives from multiple disciplines to continue engaging the field through both scholarship and advocacy.
\end{abstract}

\section{Introduction}

There is something deeply autobiographical to this issue. Crisscrossing a number of intersecting pathways, we believe this edition is reflective of personal histories, social responses to life course matters, and institutional changes in the social life cycle. But at its core this issue is a feminist and gendered view of the subject of ageing and intergenerationality. If we extend the metaphor, Agenda itself is an institution that is ageing. Having celebrated a quarter of a century this year, and growing from humble beginnings with the dedication of a small group of feminists in Durban, the journal now has continental coverage and is slowly and steadfastly approaching adulthood even though we are still in a youthful phase. At another level, the theme had a long gestation period since when it was first mooted. This edition grew out of a discussion among Editorial Advisory Board members several years ago about the need to interrogate, more closely, the prospect of ageing (and intergenerationality, precisely becauseofthetemporallinkagetomatters of biology 
and the life course) within the pages of Agenda. It is timely that we foreground the theme in a milestone year of the history of the journal. At another level, for the editors - and we assume most editors would probably say the same - it is also representative of how we too take into account our own ageing process in relation to facets of our own life course. Ageing, we realise, means much more than numbers. While Vasu and Nadia are by time-lines separated generationally, we are also simultaneously aware of the meaning, function, symbolism, and significance of the fact that age, and its attendant processes do not simply rely solely on biology and chronological time, but also on our complex interaction as individuals between society, culture and history.

Ageing is a necessary and indeed inescapable experience of being human. Also as a personal and societal problem, it sparks complex debates about assets and deficits. In fact, the deficit model of ageing as a dull, dreary dead-end is not the view we want to forge with this volume, but that rather through some of the gaps and problems that accrue, we want to also emphasise the possibility of agency and change. To this end, in this cluster issue, our focus on two interrelated themes, ageing and intergenerationality, are deliberately brought into the fold precisely because both have much to say about the fact that there is still much that we do not know, that is unexamined and indeed riddled with taboo, stigma and denial. An African focus in this edition suggests themes that offer coverage of the material context of Africa and the South by engaging some of the critical scholarship in the field.

Ageing and intergenerationality bring particular modalities and challenges in this edition that are implicit to its aim. First, we hope that it will stimulate and open up the meanings of age, ageing and intergenerationality as relevant topics; second, to enable writers to engage the complexities of these concepts in relation to the social dynamics of life course matters; and third; to give attention to new ways of thinking that may account for what may be minimised and lost should we deny and miscrecognise theseissues.

\section{A critical field of study}

Ageing and intergenerationality in the South (African context) remains remarkably under-studied except for a few texts that speak to the issue (and many ungendered) from a social policy perspective in South Africa's Eastern Cape (Sagner, 2000), the development agenda and ageing in sub-Saharan Africa (Aboderin and Ferreira, 2008), demographic (Van Dullemen, 2006), housing in South Africa (Kotze, 2006), as a pathology in respect of the institutional production of care (Myburgh, 2010), linguistics perspectives (Makoni and Stroecken, 2002), anthropological considerations on famine in rural Africa (Cligget, 2005), poverty and ageing in Uganda (Williams, 2003), intergenerational solidarity in the social security system for unemployed youth (Møller, 2010), a postmodern exploration of intergenerational practices in Africa (Hoffman, 2004), and the impact of urbanisation, impoverishment and AIDS in intergenerational relations (Geissler, Alber and Whyte, 2007). Ironically there exists a plethora of texts in northern 
scholarship that straddles a rich breadth of topics, issues and concepts and indeed, not without its controversy too. Remarkably it was especially some ageing northern feminists who took up the cudgels about the absence of ageing in discussions within the feminist project (notably Cruikshank, 2009; MacDonald and Rich, 2001; Copper, 1988). There is, however, a growing interest in ageing and intergenerationality, also as a feminist and a gender issue (Bernard, Phillips, Machin, Davies, 2000; Bengtson and Achenbaum, 1993; Izahura, 2010). Ageing and intergenerationality directs attention to relations and life course matters that rely not just on chronology or biology, but are part of a complex interaction between individual, society, culture and history (Sokolovsky, 2009; Andersson, 2002). The gender dimension of ageing, for example, is not simply confined to the "elderly" in a population, but clearly has differential implications on the life course of men and women within the broader context of class, disability, ethnicity, race and sexuality (United Nations, 2000).

A cursory review indicates that the topic of ageing and intergenerationality is remarkably rich and offers broad coverage from a number of varying fields. Some key delineations cover encyclopedic perspectives (Bengtson et al, 2009; Coyle, 2001; Dannefer and Phillipson, 2010; Johnson et al, 2005; Palmore, Whittington and Kunkel, 2009; Settersten and Angel, 2011), a history of ageing (Botelho and Thane, 2001; Johnson and Thane, 1998), and conceptual and methodological perspectives (Bond et al, 2007; Biggs, Lowenstein and Hendricks, 2003; Hillier and Barrow, 2010; Hoff, 2011a; Jamieson and Victor, 2002; Ö berg et al, 2004; Phillips et al, 2010; Vincent, 2003). Emerging gender and feminist perspectives address how gender and power relations interface with ageing (Calasanti and Slevin, 2006; Calasanti, Slevin and King, 2006; Garner, 1999; Mehta, 1997; Pearsall, 1997; Rosenthal, 1990; Vincent, 2000; Woodward, 1999); how older women experience the complex challenges of the ageing process (Poole and Feldman, 1999); ageing and the impact on gender roles (Arber and Ginn, 1995) and the resistance to the ageing process in an anti-ageing culture (Clarke, 2011).

Scholarship also covers the laws governing ageing (Doron and Soden, 2012), the policy domain, serving to reassess current social policies and options available to older people (Bass, Caro and Chen, 1993; Estes, Biggs and Phillipson, 2003; Gibson, 1998; Saraceno, 2008); fiscal and economic implications (Eich, 2004; Lee and Mason, 2010), the complexities of ageing within varying institutional arrangements (Zaidi, 2008); welfare provision and general conflict (Anxo, Bosch and Rubery, 2010; Arber and Attias-Donfut, 2008); the idea of welfare and retirement in relation to pension policies and pension systems (Ginn et al, 2001; Mann, 2001), and the social nature of later life in the context of welfare states (Gilleard and Higgs, 2005; Blome, Keck and Alber, 2009).

Ageing and intergenerationality are, therefore, not simply to be understood as linear processes of gradual, physical, and social decline, but as a dynamic and fluid process in the human and social life cycle (Austrian, 2008; Carr and Komp, 2011; 
Grenier, 2012) drawing on gender perspectives (Arber, Davidson and Ginn, 2003; Hatch, 2000); comparative biological and medical technology dimensions (Wolf, 2010); the challenges of ageing to the sexual life cycle (Hillman, 2012), and the relationship between intergenerational family ties (Connidis, 2010; Chambers et al, 2009).

Research also addresses health and the relationship between population ageing and productivity (Garibaldi, Martins and Van Ours, 2010), and the relationship between and the influence of culture, health, social context and change on ageing (Backes, Lasch and Reimann, 2006; Phillipson, 2008; Weisstub et al, 2010). The material, relational and cultural dynamics of ageing and intergenerationality also shape and construct people's diverse life experiences through narrative constructions of experience and identity (Chapman, 2005). In what is now considered a classic in anthropological writing on ageing, Cohen (1998) presents a rich ethnographic argument on senility in India to caution against reducing Alzheimer's to pure biology, and rather to claim that it also reveals deep-seated social differentiation. In this regard, scholarship suggests that ageing brings with it much diversity in a globalised context (Baars et al, 2006; Bengtson and Lowenstein, 2003); uneven population ageing (Davies and James, 2011), and new meanings in relation to nostalgia and remembrance of things past (Ray, 2000). In addition, ageing also brings experiences of loss (Brown, 2008; Graham and Stephenson, 2010). And there is much to tell in the narratives of ageing widows (Chambers, 2005; Jenkins, 2003), as well as about the specific needs of older men adjusting as resilient widowers (Moore and Stratton, 2003). There is also much to be gained with the visibility that experiences of being between 50 and 70 brings to challenge social exclusion (Bell, 2012), and much to learn via a rich ethnography of rural Bengali women's construction of ageing and embodiment (Lamb, 2000). Noting that age forms part of the individual's personal identity, people are also caught up with the obsession to stay young (Gullette, 2004), drawing into the arguments ideas about resistance to the ageing process (Slevin, 2010).

A significant corpus of texts also exists on discrimination and diversity in the field of ageing research that concerns, for example, inclusion and exclusion in respect of social cohesion (Scharf and Keating, 2012), and age discrimination and ageism (Sargeant, 2011). At a conceptual level, Macnicol (2006) considers the historical dimensions of age discrimination in relation to employment and the impact of mandatory retirement. In an earlier study, Nelson (2004) examined both conceptual and empirical aspects addressing the origins and effects of ageism and potential correctives to such prejudice. In another study, Daatland and Biggs (2006) assess the stereotypes of ageing and offer perspectives from a transnational perspective in relation to older migrants and ageing identities. Marginalised sexualities (with a focus on gay and lesbian populations) address the experiences and challenges faced by gay men and women (Brown et al, 1997; Brown, 2009; Sears, 2009; Witten and Eyler, 2012). 
Comparative and country-specific studies have also considered demographic trends in a range of geopolitical contexts. For example, Phillips (2000) considers the impact of ageing, including its structural and behavioural impact on older persons in one of the world's largest ageing populations in the Asian-Pacific region. Coulmas (2007) considers population decline and ageing in Japan, while Hoff (2011b) examines the context of Central and Eastern Europe. Teo et al (2006) examine the ageing population of Singapore in relation to their service needs and the role of the state. Turning to Australia, Borowski et al (1998) provide a perspective on ageing and social policy in the Australian context by drawing into their argument, analysis around women and Aboriginal Australians. In their comparison of Sri Lanka, India and the Netherlands, Rajan et al (2008) examine the institutional provisions of care for the aged. And in drawing lessons from three multicultural nations (United States, Israel and Australia), Carmel (2007) focuses on the problems and challenges related to care and caregiving of the aged.

Consumption patterns of ageing populations also fall under the spotlight where the role of older persons as consumers and their experiences are examined (Jones et al, 2008; Hedrick-Wong, 2006). Another study examining perceptions and media images investigates consumption patterns of various goods, indicating that there is an extended leisure phase for the elderly known as the Third Age (Blaikie, 1999). Contrary to popular perception, older persons are active agents in economic consumption.

The relationship between ageing and the criminal justice system from the perspective of criminology and gerontology have also addressed the implications for older people as victims and perpetrators of crime (Wahidin and Cain, 2006). The broader question of social security, family and public support is examined in case studies of gender and social security in India and Burkina Faso (De Jong et al, 2005).

Perspectives on broad human and social development have prioritised analysis of adult development into old age in respect of experiences related to physical, mental and psychological development (Coleman and O'Hanlon, 2004; Ryan and Coughlan, 2011; Stuart-Hamilton, 2006); rural ageing (Keating, 2008); urban ageing (Smith, 2009); the meaning of space and place (Andrews and Phillips, 2005), as well as transcending the myths for women who age (Gannon, 1999). Ageing also opens up concerns with ethical issues around care, disability and the incorporation of a spiritual dimension and pathways in well-being (Mackinlay, 2008; Coleman, 2011), as well as contexts of care and work in which the elderly find themselves (Lechner and Neal, 1999; Martin-Matthews and Phillips, 2008), and general concerns with improvements to a quality of life (Mollenkopf and Walker, 2010).

The Humanities dimension on ageing has often provided insight into the meaning attached to creativity in relation to ageing (Cole et al, 2000); cultural proscriptions on artists; on embodiment and dance, and the challenges faced by older dancers

\section{http://repository.uwc.ac.za}


(Schwaiger, 2012). Literary representation on ageing and gender is also explored in relation to fictional depictions of older female protagonists (Brennan, 2005); the impact of growing older and psychological development (Wyatt-Brown and Rossen, 1993); ageing as a theme in Indian writing (Raja, 2009); positive perspectives of the ageing experience in memoirs, stories and poetry (Weinberg, 2006), and the value of narrative gerontology (Kenyon, Bohlmeijer and Randall, 2011) in storytelling about ageing (Hepworth, 2000).

The broad coverage of scholarship on ageing and intergenerationality confirms that this is a field replete with new ideas and some cutting edge research, but still sadly very largely focused on northern contexts, and to a lesser extent the East. There is no doubt from our assessment that there is a dearth of scholarship, and we hope that contributions to this edition will reinforce debate, discussion and perspective from an African perspective.

Overview of the Special Issue Writers in this edition engage multiple perspectives around ageing, gender and intergenerationality, or otherwise draw consequential readings from these concepts. While distinctive in each contribution, the pieces are in conversation with each other, attesting to the significance of feminist dialogue in sub-Saharan Africa on ageing as it intersects with, for example, gender, sexuality, class, culture, and place. Within globalised discourses that position youth and reproductive sexualities as desirable, the writing in this special issue brings to light concerns with intergenerational sex, early childbearing, and the potential role of sex worker activists in providing creative education and awareness to young women and older men. But also important is a common idea that is at times implicit in the writing, namely that ageing is never a homogeneous process, but rather is profoundly mediated by gender, race, class, and place. While a feminist and gendered lens on ageing enables perspectives that take into account how gender matters as we age, we believe that contributions to this edition also offer at times intersectional views as well. Intersectional approaches to ageing in some of the contributions is significant when considering how gender and ageing interlink, and how we experience being an elderly person.

Makiwane, Ndinda and Botsis' Article presents an important analysis of the 2010 General Household Survey data, revealing how race, gender and ageing intersect in the current South African context. Distinguishing between chronological age and functional age, the writers astutely point out that the intersections of race, class and gender impacts on our experience of ageing, with black poor women experiencing ageing "qualitatively worse than that of other social categories of the elderly"(p 26).

Such an analysis is critical in understanding how ageing is inextricably linked to the social conditions in which we are located, and how conditions of struggle affect the lives we are able to lead as elderly persons. 
In her Briefing on the differential socio-economic effects of neo-liberalism on women in Ibadan, Nigeria, Grace Adeniyi-Ogunyankin cautions that "longer life must be accompanied by improvement in the quality of life experience for those who reach that age" ( $p$ 30). The effects of neo-liberalism in Ibadan contribute to classed and spatial consequences, so that low-income elderly women are affected negatively. Consequently, strained economic conditions mean that these women's experiences of ageing are tied to the economic well-being of their families. For lowerincome women, this entails contributing financially to the care of children and grandchildren to a greater extent than elderly women who are economically more secure.

Similarly, in the South African context, Vivienne Bozalek and Nancy R Hooyman confirm the view that the burden of care falls primarily on women, including poorer elderly women in strained socio-economic familial contexts. Using a political ethics of care and feminist gerontology perspective in considering the life course experience, they argue that older women are both the receivers and givers of care, with grandmothers often being the primary caregivers of children and grandchildren in poorer homes. Bozalek and Hooyman advocate for a redefinition of care "as a societal responsibility requiring adequate resources rather than the responsibility of a particular group of people" (p 38). Based on interviews with a group of students from the University of the Western Cape in South Africa, the authors reveal cultural and religious values that are resistant to old age homes as a space for elderly grandparents. Consequently, it is women family members who become the primary caregivers to their elderly parents/grandparents, with little or no recognition and support from the state.

Feminist takes on 'sugar daddies', transactional sex, and HIV in the sub-Saharan African context has been well documented, and continues to be of concern to scholars and activists across disciplines. In this edition, the authors provide an alternative lens in reading intergenerational sexual relations in the contemporary South African context. In an Open Forum in response to the stigmatisation of cross-generational sex articulated in a KwaZulu-Natal campaign, Pierre Brouard and Mary Crewe suggest that "a more nuanced, historically informed" ( $\mathrm{p}$ 55) approach needs to accompany our questions about the relatively common practice of intergenerational sex. The authors argue for an acceptance of transactionality that understands the practice as valid human conduct, particularly where material conditions underpin such relationships. Campaigns that work against transactional sex through stigmatisation of young women, in particular, are according to the authors, "attempts to control the sexuality of young people" ( $p$ 55) in ways that signify our societal denial about a range of other social phenomena, such as high levels of divorce, and the fiction of monogamy as an appropriate HIV preventative measure.

Keeping with the theme of sugar daddies, Tamara Shefer and Anna Strebel add another dimension to the discussions on intergenerational relationships in their 
Focus article. Arguing for a move away from depicting men centrally as "perpetrators of unequal sexual relationships with youngerwomen"( $\mathrm{p}$ 57), theauthors suggest more critical feminist analysis is required to better understand men's constructions of sexuality, and their investments in intergenerational relationships. Reflecting similar concerns to those raised by Brouard and Crewe, Shefer and Strebel advocate for a "self-reflexive" approach that critiques the notion of all intergenerational relationships as "inherently exploitative" (p 58).

Gabrielle le Roux's extraordinary portraits in the Living Ancestors exhibition is an excellent representation of the focus of this special edition. Showcasing her work from this exhibition, Gabrielle's portraits of Dominican women - most of whom are over 100-years old - allow us a glimpse into these women's lives. In conversation with Nadia Sanger, Gabrielle tells us about her experiences as a feminist artist and activist, the politics behind and within her work, and why the opportunity to work with the women in creating Living Ancestors was so significant for her. These portraits are moving images of material lives written and etched into the faces of magnificent women with deep histories.

Nolwazi Mkhwanazi's Article focuses on how the discourse on teenage motherhood by South African government officials and the black elite in the contemporary Zuma era, serves to demonise young mothers. Motivating that government policies and programmes, predicated upon a better life for all, do not consider the conditions that disable young women from achieving this goal, Mkhwanazi contends that highly patriarchal and violent value systems enable a policing of young women's fertility. An effect of this, according to Mkhwanazi, is that it allows for teenage mothers, in this instance, to be punished for deviating from the life trajectory that is imagined to underpin 'a better life for all'. In this Article, Mkhwanazi makes the case for a broader understanding of the conditions in which teenage pregnancy comes about, and challenges a punitive approach to young motherhood.

Based on findings from an ethnographic study in the Peruvian Amazon, Yasmin Lalani discusses how female sex worker activists use various education initiatives to raise awareness about HIV among young women and older men. Lalani describes her conversations with sex worker activists (SWAs) who articulate concerns about young women on 'The Boulevard'engaging in transactional and intergenerational sex with local and tourist men, but refuse to claim the label 'sex worker', disallowing the HIV/AIDS education offered to them by SWAs. The SWAs' conversations with older male clients about HIV preventative measures are interestingly exposed in this Briefing, highlighting sex workers' creative engagement around condom use with their male clients.

The idea that older people lack sexual desire and intimacy is carefully interrogated in the critical Briefing by Gloria Chepngeno-Langat and Victoria Hosegood. The idea that somehow old age minimises sexuality, is challenged in their reading of older 
people and sexuality in sub-Saharan Africa. The focus that almost exclusively in subSaharan Africa falls on young persons, reproduction, and HIV and AIDS, implying that older people are largely asexual, is dealt a serious blow in this perspective. The authors discuss how various religious and spiritual beliefs construct sexuality in ways that exclude older persons, particularly older women, as desiring sexual subjects. This, the authors argue, has serious consequences for older people's health, especially under conditions where medical advice is sought.

In an Article on women's positive personhood in Manenberg in the Western Cape, Anna Versfeld deliberates on her ethnographic research that sees a removal of the resources once available to women under apartheid, and no longer accessible to younger women in the post-apartheid space. Representing the life histories of two women across generations in Manenberg, Versfeld explains that younger women are finding it harder to construct positive personhood due to the macro-political economic shifts post-apartheid.

Nompumelelo Thabethe and Lucy Chioma Usen zone in on older women's rights in home-based care in the Nigerian and South African contexts. Situating the oppression of older women as central to feminist concerns, in this Briefing the authors discuss how older women's labour, as the primary caregivers of people living with HIV and AIDS, orphans and vulnerable children, is "invisible in both policy and practice” ( $p$ 114). Older women's labour in caring for the ill within impoverished contexts, the authors posit, is expected by governments who do not provide the necessary support for these women, who have emotional and physical requirements of their own.

In their Briefing, Manase Kudzai Chiweshe and Mandida Gusha tackle the struggles experienced by older women in Bako Redonhodzo Old People's Home in Harare, Zimbabwe during the country's economic and political crisis in 2008. The authors' life history interviews with 10 women at the Home, depict the latter's difficulties to survive in a context where the lack of a policy on elderly care means further neglect and marginalisation within a country in crisis. The recently instituted (2011) Zimbabwean Older Persons' Bill is a highly significant step taken by the government to prevent discrimination and prioritise the needs of older people.

The Report in this special issue, while not directly addressing the theme of ageing, is a timely reflection of a forum discussion on 'The state of women's health' which focused on an Agenda special issue, edited by Mandisa Mbali and Sethembiso Mthembu. This forum allowed for an intense discussion between some of the journal contributors and the Deputy Minister of Health, Dr Gwen Ramokgopa. Through a feminist lens, the Report highlights women's health concerns, and the policies and commitments by government and civil society in working towards a comprehensive women's health 
policy that should make central the various health needs of women and the required government services in order to provide for these needs.

In this issue, the Profile authored by seven women academics from the University of Limpopo's Women's Academic Solidarity Association, reminds us of the challenges that black women academics continue to face in higher education institutions. The women's narratives in this Profile draw attention to the importance of collaboration and support between women at academic institutions, where "values of individualism and subjectivity ... pre-empt any possibility of real dialogue and transformation" ( $\mathrm{p}$ 145). This Profile reminds us of the significance of feminist thought and feminist solidarity, and the possibilities that emerge when women work together and use their agency to create a space where they can progress and excel in their academic work.

A life steeped in a difficult and simultaneously rich history is Ethiopian-born, Hannah Yilma. In her interview with Vasu Reddy, Hannah provides a candid account of a multifaceted and indeed multilayered life in politics, war, her family and survival.

Two book reviews are included in this special issue. Benita Moolman provides a critical reading of Mark Hunter's (2010) Love in the Time of AIDS: Inequality, Gender and Rights in South Africa, and Amanda Mtshengu offers a perspective on Vicci Tallis' recently published (2012) Feminisms, HIV and Aids: Subverting Power, Reducing Vulnerability.

\section{Conclusions}

Veneration of the elderly, widely accepted in many cultures, is premised on the idea that honour and respect is accorded to those who have achieved old age, and the notion that it is also a time to rest from work. Yet, elderly women, as the research contributions in this issue testify to, are among one of the most poverty-stricken groups, among the hardest working as caregivers and the most socially resourceful, yet are far from receiving the social respect that they deserve. In this sense, investing in longevity research therefore cannot be overstated (Warner and Sierra, 2009). Feminist attention to the gender inequalities that are experienced by the elderly, as a socially vulnerable group, has not been notably significant, and is not an identifiable priority in the Beijing Platform of Action. Ageism and the social prejudice which results in the elderly as a social group being constructed as having no social value, social needs or the capacity to participate in the decisions that affect their lives, need to be challenged. Indeed many countries in Africa, including South Africa, have yet to implement a comprehensive policy to protect the rights of the elderly and gendersensitive approaches that addresses the gender-specific needs of women and men. This issue has sought to open up such debate and it will hopefully stimulate further inquiry on gender, ageing and intergenerationality. 
Compiling this issue has enabled us, the guest editors, to consider the depth and range of possible issues that ageing and intergenerationality opens up. If the ideas and issues contained in this volume remain of interest that is, at least in part, because we still have much more to explore and learn, as some recent studies focused on gender and ageing are suggesting (Leathwood and Francis, 2006; Kaplan and Kuntz, 2008). We hope the ideas contained in this volume provoke further discussion and continue the conversation. We are only beginning to scratch the surface of this topic in the African context. The pieces in this special issue weave well, we think, the empirical, policy, programmatic, conceptual and indeed, the methodological.

But we should conclude these comments by indicating that our framing is not a definitive guide to all arguments. We have said that each contribution offers its unique elaboration and expression, and leave you, the reader, to make your own decisions as you rethink ageing and intergenerationality as modalities that matter in the gender spectrum. The idea that age matters is a real, tangible and material reality inasmuch as it is also an epistemological issue worthy of further gendered and feminist investigation in Africa.

\section{Acknowledgements}

The guest editors of this issue acknowledge the authors who contributed to this edition, and are indebted to the various reviewers who painstakingly and rigorously assisted with manuscript reviews, including also reviews of revisions. Consistently helpful guidance, support and advice from Managing Editor, Lou Haysom, as well as the Editorial Advisory Group of Agenda has been deeply appreciated. Special thanks to colleagues, friends, partners, family and friends, some of whom need special mention in no order of priority: Lebo Moletsane, Errolyn Long, Sudeshan Reddy, Damian Samuels, Tommy Sanger (1925 - 2012), and Appiammah Reddy (1917 - ). 


\section{References}

Aboderin I \& Ferreira M (2008) 'Linking ageing to development agendas in subSaharan Africa: Challenges and approaches' in Population Ageing, 1, 1, 51-73.

Andersson L (2002) Cultural Gerontology, Westport, Conn.: Auburn House.

Andrews GJ \& Phillips DR, (eds) (2005) Ageing and Place: Perspectives, Policy, Practice, London and New York: Routledge.

Anxo D, Bosch G \& Rubery J, (eds) (2010) The Welfare State and Life Transitions: A European Perspective, Cheltenham, UK: Edward Elgar Publishing.

Arber S \& Ginn J, (eds) (1995) Connecting Gender and Ageing: A Sociological Approach, ${ }_{1}{ }^{\text {st }}$ edition, Berkshire, UK: Open University Press.

Arber S \& Attias-Donfut C (2008) The Myth of Generational Conflict: The Family and State in Ageing Societies, London and New York: Routledge.

Arber S, Davidson K \& Ginn J, (eds) (2003) Gender and Ageing: Changing Roles and Relationships, Berkshire, UK: Open University Press.

Austrian SG (2008) Developmental Theories Through the Life Cycle (2nd ed), New York: Columbia University Press.

Baars J, Dannefer D, Phillipson C \& Walker A, (eds) (2006) Aging, Globalization and Inequality: The New Critical Gerontology, Amityville, New York: Baywood Publishing Company, Inc.

Backes GM, Lasch V \& Reimann K, (eds) (2006) Gender, Health and Ageing: European Perspectives on Life Course, Health Issues and Social Challenges, Wiesbaden: VS Verlag.

Bass SA, Caro FG \& Chen Y, (eds) (1993) Achieving a Productive Aging Society, Westport, Connecticut \& London: Auburn House.

Bell C (2012) Visible Women: Tales of Age, Gender and In/visibility, Newcastle upon Tyne, UK: Cambridge Scholars Publishing.

Bengtson VL \& Achenbaum WA, (eds) (1993) The Changing Contract Across Generations, New York: de Gryter.

Bengtson VL \& Lowenstein A (2003) Global Aging and Challenges to Families, New Jersey: Aldine Transaction Publishers.

Bengtson VL, Gans D, Putney N \& Silverstein M, (eds) (2009) Handbook of Theories of Aging, 2nd ed, New York: Springer Publishing Company.

Bernard M, Phillips JC, Machin, L \& Davies VH, (eds) (2000) Women Ageing: Changing Identities, Challenging Myths, New York \& London: Routledge.

Biggs S, Lowenstein A \& Hendricks J, (eds) (2003) The Need for Theory: Critical approaches to Social Gerontology, Amityville, NY: Baywood Publishing Company, Inc.

Blaikie A (1999) Ageing and Popular Culture, Cambridge: Cambridge University Press.

Blome A, Keck W \& Alber J (2009) Family and the Welfare State in Europe: Intergenerational Relations in Ageing Societies, Cheltenham, UK: Edward Elgar Publishing. 
Bond J, Peace SM, Dittmann-Kohli F \& Westerhof G, (eds) (2007) Ageing in Society: European Perspectives on Gerontology, 3rd ed, London: Sage Publications Ltd.

Borowski A, Encel S, Ozanne, E, (eds) (1998) Ageing and Social Policy in Australia, Cambridge: Cambridge University Press.

Botelho LA \& Thane P, (eds) (2001) Women and Ageing in British Society Since 1500, Harlow, UK: Longman Pub Group.

Brennan Z (2005) The Older Woman in Recent Fiction, Jefferson, NC: Mcfarland \& Company, Inc. Publishers.

Brown G (2008) The Living End: The Future of Death, Ageing and Immortality, New York: Macmillan.

Brown MT (2009) 'LGBT aging and rhetorical silence', in Sexuality Research \& Social Policy: Journal of NSRC, 6, 4, 65-78.

Brown LB, Sarosy S, Cook TC \& Quarto JG (1997) Gay Men and Aging, New York and London: Routledge.

Calasanti TM, Slevin KF \& King N (2006) 'Ageism and feminism: From "et cetera" to center', in Feminist Formations, 18, 1, 13-30.

Calasanti TM \& Slevin KF, (eds) (2006) Age Matters: Re-aligning Feminist Thinking, New York: Routledge.

Carmel S, Morse CA \& Torres-Gil FM, (eds) (2007) Lessons on Aging from Three Nations, Amityville, New York: Baywood Publishing Company.

Carr DC \& Komp KS, (eds) (2011) Gerontology in the Era of the Third Age: Implications and Next Steps, New York: Springer Publishing Company.

Chambers P, Allan G, Phillipson C \& Ray M (2009) Family Practices in Later Life, Bristol: Policy Press.

Chambers P (2005) Older Widows and the Life Course: Multiple Narratives of Hidden Lives, Aldershot, UK and Burlington, US: Ashgate Publishing Limited.

Chapman SA (2005) 'Theorizing about Aging Well: Constructing a Narrative' in Canadian Journal on Aging, 24, 1: 9-18.

Clarke LH (2011) Facing Age: Women Growing Older in Anti-aging Culture, Lanham, Boulder, New York, Toronto and Plymouth, UK: Rowman \& Littlefield Publishers, Inc.

Cliggett L (2005) Grains from Grass: Aging, Gender, and Famine in Rural Africa, Ithaca, New York: Cornell University Press.

Cohen L (1998) No Ageing in India: Alzheimer's, the Bad Family, and Other Modern Things, Berkeley and Los Angeles: University of California Press.

Cole TR, Kastenbaum R \& Ray RE, (eds) (2000) Handbook of the Humanities and Aging, ${ }_{2}^{\text {nd }}$ edition, New York: Springer Publishing Company.

Coleman PG \& O'Hanlon A (2004) Ageing and Development: Theories and Research, New York: Oxford University Press.

Coleman PG, (ed) (2011) Belief and Ageing: Spiritual Pathways in Later Life, Bristol: Policy Press. 
Connidis IA (2010) Family Ties and Aging ( $2^{\text {nd }}$ edition), Los Angeles and London: Pine Forge Press (imprint of Sage Publications).

Copper B (1988) Over the Hill: Reflections on Ageism between Women, Freedom, CA: The Crossing Press.

Coulmas F (2007) Population Decline and Ageing in Japan - The Social Consequences, Oxford and New York: Routledge.

Coyle, JM, (ed) (2001) Handbook on Women and Aging, Westport, CT: Praeger Publishers.

Cruikshank M (2009) Learning to be Old: Gender, Culture, and Aging (2nd edition), Plymouth: Rowman and Littlefield Publishers.

Daatland SO \& Biggs S, (eds) (2006) Ageing and Diversity: Multiple Pathways and Cultural Migrations, Bristol: Policy Press.

Dannefer D \& Phillipson C, (eds) (2010) The SAGE Handbook of Social Gerontology, London: Sage Publications Ltd.

Davies A \& James A (2011) Geographies of Ageing: Social Processes and the Spatial Unevenness of Population Ageing, Surrey, UK and Burlington, VT: Ashgate Publishing Ltd.

de Jong W, Roth C, Badini-Kinda F \& Bhagyanath S (2005) Ageing in Insecurity: Case Studies on Social Security and Gender in India and Burkina Faso, Mü nster: Lit Verlag.

Doron I \& Soden AM, (eds) (2012) Beyond Elder Law: New Directions in Law and Aging, Berlin and Heidelberg: Springer-Verlag.

Eich F (2004) 'Fiscal problems posed by ageing populations', in SAIS Review, 24, 2, 93104.

Estes C, Biggs S \& Phillipson C (2003) Social Theory, Social Policy and Ageing: A Critical Introduction, Berkshire, UK: Open University Press.

Gannon LR (1999) Women and Aging: Transcending the Myths, London and New York: Routledge.

Garibaldi P, Martins JO \& Oliveira JM, (eds) (2010) Ageing, Health, and Productivity: The Economics of Increased Life Expectancy, Oxford: Oxford University Press.

Garner JD, (ed) (1999) Fundamentals of Feminist Gerontology, London and New York: Routledge.

Geissler W, Alber E \& Whyte S, (eds) (2007) Grandparents and Grandchildren. Edinburgh: Edinburgh University Press.

Gibson D (1998) Aged Care: Old Policies, New Problems, Cambridge: Cambridge University Press.

Gilleard C \& Higgs P (2005) Contexts of Ageing: Class, Cohort and Community, Bristol: Polity.

Ginn J, Street D \& Arber S, (eds) (2001) Women, Work and Pensions: International Issues and Prospects. Buckingham and Philadelphia: Open University Press.

Graham JE \& Stephenson PH, (eds) (2010) Contesting aging and loss, Toronto: University of Toronto Press.

Grenier A (2012) Transitions and the Lifecourse: Challenging the Constructions of 'Growing Old', Bristol: Policy Press. 
Gullette MM (2004) Aged by Culture, Chicago and London: University Of Chicago Press.

Hatch LR (2000) Beyond Gender Differences: Adaptation to Aging in Life Course Perspective, Amityville, New York: Baywood Publishing Company, Inc.

Hedrick-Wong Y (2006) The Glittering Silver Market: The Rise of the Elderly Consumers in Asia, Singapore: John Wiley \& Sons.

Hepworth M (2000) Stories of Ageing, Buckingham \& Philadelphia: Open University Press.

Hillier SM \& Barrow GM (2010) Aging, the Individual, and Society, Belmont, CA: Wadsworth Publishing.

Hillman J (2012) Sexuality and Aging: Clinical Perspectives, New York and Heidelberg: Springer.

Hoff A (2011a) 'Long-term challenges of studying intergenerational relationships in research and practice', in Journal of Intergenerational Relationships, 9, $1,1-6$.

Hoff A (2011b) Population Ageing in Central and Eastern Europe: Societal and Policy Perspectives, Surrey: Ashgate Publishing Company.

Hoffmann J (2004) “... . the (unbearable) in-betweenness' of being .. .”: a postmodern exploration of intergenerational practices in Africa: A framework towards programming', in Journal of Intergenerational Relationships, 2, 3-4, 197-213.

Izahura M (2010) Ageing and Intergenerational Relations: Family Reciprocity from a Global Perspective, Bristol: Policy Press.

Jamieson A \& Victor CR (2002) Researching Ageing and Later Life, Buckingham: Open University Press.

Jenkins CL, (ed) (2003) Widows and Divorcees in Later Life: On Their Own Again, Binghamton, New York: Harrington Park Press.

Johnson P \& Thane P, (eds) (1998) Old Age from Antiquity to Post-modernity, London: Routledge.

Johnson ML, Bengtson VL, Coleman PG \& Kirkwood TBL, (eds) (2005) The Cambridge Handbook of Age and Ageing, Cambridge: Cambridge University Press.

Jones IR, Hyde M, Victor CR, Wiggins RD, Gilleard C \& Higgs P (2008) Ageing in a Consumer Society: From Passive to Active Consumption in Britain, Bristol: Policy Press.

Kaplan C \& Kuntz S (2008) You can't be old before you are young: Aging and pedagogy' in Feminist Teacher, 18, 2,145-144.

Keating N, (ed) (2008) Rural Ageing: A Good Place to Grow Old?, Bristol: Policy Press.

Kenyon G, Bohlmeijer E \& Randall WL, (eds) (2011) Storying Later Life: Issues, Investigations, and Interventions in Narrative Gerontology, New York: Oxford University Press.

Kotze N (2006) 'Housing the elderly in South Africa: A Free State case study', in South African Geographical Journal, 88, 1, 32-38.

Krog A (2006) Body Bereft, Cape Town: Umuzi. 
Lamb S (2000) White Saris and Sweet Mangoes: Aging, Gender, and Body in North India, Berkeley and Los Angeles: University of California Press.

Leathwood C \& Francis B, (eds) (2006) Gender and Lifelong Learning: Critical Feminist Engagements, Oxford and New York: Routledge.

Lechner VM \& Neal MB, (eds) (1999) Working and Caring for the Elderly: International Perspectives, London and New York: Routledge.

Lee R \& Mason A (2010) 'Some macro-economic aspects of global population aging', in Demography, 41, supplement, 151-172.

MacDonald B \& Rich C (2001) Old Women, Aging and Ageism, Midway, Florida: Spinsters Ink Books.

Mackinlay E, (ed) (2008) Ageing, Disability and Spirituality: Addressing the Challenge of Disability in Later Life, London and Philadelphia: Jessica Kingsley Publishers.

Macnicol J (2006) Age Discrimination: An Historical and Contemporary Analysis, Cambridge: Cambridge University Press.

Makoni S \& Stroecken K, (eds) (2002) Ageing in Africa: Sociolinguistic and Anthropological Approaches. Aldershot, UK and Burlington, US: Ashgate Publishing Company, Inc.

Mann K (2001) Approaching Retirement: Social Divisions, Welfare and Exclusion, Bristol: Policy Press.

Martin-Matthews A \& Phillips JE, (eds) (2008) Aging and Caring at the Intersection of Work and Home Life: Blurring the Boundaries, London and New York: Psychology Press.

Mehta K, (ed) (1997) Untapped Resources: Women in Ageing Societies Across Asia, Singapore: Marshall Cavendish Academic.

Mollenkopf H \& Walker A, (eds) (2010) Quality of Life in Old Age: International and Multi-Disciplinary Perspectives, Dordrecht, Netherlands: Springer.

Møller V (2010) 'Strengthening intergenerational solidarity in South Africa: closing the gaps in the social security system for unemployed youth - a case study of the "perverse incentive", in Journal of Intergenerational Relationships, 8, 2, 145160.

Moore AJ \& Stratton DC (2003) Resilient Widowers: Older Men Adjusting to a New Life, Amherst, New York: Prometheus Books.

Myburgh H (2010) 'Ageing as 'pathology': The institutional production of care, time and the elderly subject in Stellenbosch', in South African Review of Sociology, 41, 2, 5-14.

Nelson TD, (ed) (2004) Ageism: Stereotyping and Prejudice against Older Persons, Cambridge, MA: MIT Press.

Ö berg B, Na“ rva“ nen A, Na“ sman E \& Olsson E, (eds) (2004) Changing Worlds and the Ageing Subject: Dimensions in the Study of Ageing and Later Life, Aldershot, UK \& Burlington, VT: Ashgate Publishing Ltd.

Palmore E, Whittington F \& Kunkel S, (eds) (2009) The International Handbook on Aging: Current Research and Developments, Santa Barbara, CA, Denver, Colorado: Praeger. 
Pearsall M, (ed) (1997) The Other Within Us: Feminist Explorations of Women and Aging, Boulder, Colorado: Westview Press.

Phillips DR, (ed) (2000) Ageing in the Asia-Pacific Region: Issues, Policies and Future Trends, London and New York: Routledge.

Phillips J, Ajrouch K \& Hillcoat-Nalle' tamby S (2010) Key Concepts in Social Gerontology, London and Thousand Oaks, CA: Sage Publications.

Phillipson C, (ed) (2008) Social Issues of Ageing, London and New York: Routledge.

Poole M \& Feldman S, (eds) (1999) A Certain Age: Women Growing Older, St Leonards, Australia: Allen \& Unwin.

Raja I, (ed) (2009) Grey Areas: An Anthology of Contemporary Indian Fiction on Ageing, New York: Oxford University Press.

Rajan SI, Risseeuw C \& Perera M, (eds) (2008) Institutional Provisions and Care for the Aged: Perspectives from Asia and Europe, New Delhi and London: Anthem Press.

Ray RE (2000) Beyond Nostalgia: Aging and Life-story Writing, Charlottesville, VA: University of Virginia Press.

Rosenthal ER, (ed) (1990) Women, Aging and Ageism, Binghamton, New York: The Haworth Press.

Ryan P \& Coughlan BJ, (eds) (2011) Ageing and Older Adult Mental Health: Issues and Implications for Practice, East Sussex, UK \& New York: Routledge.

Sagner A (2000) 'Ageing and social policy in South Africa: Historical perspectives with particular reference to the Eastern Cape', in Journal of Southern African Studies, 26, 3, 523-553.

Saraceno C, (ed) (2008) Families, Ageing and Social Policy: Intergenerational Solidarity in European Welfare States, Cheltenham, UK \& Northampton, MA, USA: Edward Elgar Publishing.

Sargeant M, (ed) (2011) Age Discrimination and Diversity: Multiple Discrimination from an Age Perspective, Cambridge: Cambridge University Press.

Scharf T \& Keating NC, (eds) (2012) From Exclusion to Inclusion in Old Age: A Global Challenge, Bristol: Policy Press.

Schwaiger E (2012) Ageing, Gender, Embodiment and Dance, London and New York: Palgrave Macmillan.

Sears JT, (ed) (2009) Growing Older: Perspectives on LGBT Aging, Oxford and New York: Routledge.

Settersten RA \& Angel JL, (eds) (2011) Handbook of Sociology of Aging, New York \& London: Springer.

Singh K (2012) The Freethinker's Prayer Book, New Delhi: Aleph Book Company.

Slevin KF (2010) "If I had lots of money ... I'd have a body makeover:" Managing the aging body', in Social Forces, 88, 3. 1003-1020.

Smith AE (2009) Ageing in Urban Neighbourhoods: Place Attachment and Social Exclusion, Bristol: Policy Press.

Sokolovsky J, (ed) (2009) The Cultural Context of Ageing: Worldwide Perspectives, $3^{\text {rd }}$ edition, Westport, CT: Praeger. 
Stuart-Hamilton I (2006) The Psychology of Ageing: An introduction (4th edition), London and Philadelphia: Jessica Kingsley Publishers.

Teo P, Mehta K, Thang LL \& Chan A (2006) Ageing in Singapore: Service Needs and the State, Oxford and New York: Routledge.

United Nations (2000) Ageing in a Gendered World: Women's Issues and Identities, Santa Domingo, DR: INSTRAW.

Van Dullemen C (2006) 'Older people in Africa: New engines to society?', in Feminist Formations, 18, 1: 99-105.

Vincent JA (2000) Politics, Power and Old Age, Buckingham, UK and Philadelphia: Open University Press.

Vincent J (2003) Old Age: Key Ideas, London and New York: Routledge.

Wahidin A \& Cain M, (eds) (2006) Ageing, Crime and Society, Portland and Devon: Willan Publishing.

Warner HR \& Sierra F (2009) The longevity dividend: Why invest in basic aging research?', in Canadian Journal on Aging, 28, 4, 391-394.

Weinberg JA, (ed) (2006) Still Going Strong: Memoirs, Stories, and Poems about Great Older Women, Binghamton, New York: The Haworth Press.

Weisstub DN, Thomasma DC, Gauthier S, \& Tomossy GF, (eds) (2010) Aging: Culture, Health, and Social Change, Dordrecht, Boston and London: Kluwer Academic Publishers.

Williams A (2003) Ageing and Poverty in Africa: Ugandan Livelihoods in a Time of HIV/Aids, Aldershot, UK and Burlington, VT: Ashgate Publishing Limited.

Witten TM \& Eyler AE, (eds) (2012) Gay, Lesbian, Bisexual, and Transgender Aging: Challenges in Research, Practice, and Policy, Baltimore: The Johns Hopkins University Press.

Wolf NS, (ed) (2010) Comparative Biology of Aging, Dordrecht and Heidelberg: Springer.

Woodward K, (ed) (1999) Figuring Age: Women, Bodies, Generations, Bloomington \& Indianapolis: Indiana University Press.

Wyatt-Brown AM \& Rossen J (1993) Aging and Gender in Literature: Studies in Creativity, Charlottesville and London: University of Virginia Press.

Zaidi A (2008) Well-being of Older People in Ageing Societies (Public Policy and Social Welfare), Aldershot, UK and Burlington, VT: Ashgate Publishing Company. 